Cornell Law Library

Scholarship@Cornell Law: A Digital Repository

Cornell Law Faculty Publications

Faculty Scholarship

$5-2014$

\title{
Searching for the Hinterman: In Praise of Subjective Theories of Imputation
}

Jens David Ohlin

Cornell_Law School, jdo43@cornell.edu

Follow this and additional works at: http://scholarship.law.cornell.edu/facpub

Part of the Criminal Law Commons, and the International Law Commons

\section{Recommended Citation}

Ohlin, Jens David, "Searching for the Hinterman: In Praise of Subjective Theories of Imputation" (2014). Cornell Law Faculty Publications. Paper 938.

http://scholarship.law.cornell.edu/facpub/938

This Article is brought to you for free and open access by the Faculty Scholarship at Scholarship@Cornell Law: A Digital Repository. It has been accepted for inclusion in Cornell Law Faculty Publications by an authorized administrator of Scholarship@Cornell Law: A Digital Repository. For more information, please contact jmp8@cornell.edu. 


\title{
Searching for the Hinterman
}

\author{
In Praise of Subjective Theories of Imputation
}

\author{
Jens David Ohlin*
}

\begin{abstract}
How should international courts distinguish between principals and accessories? The ICC answered this question with Roxin's Control Theory of Perpetration; defendants should be convicted as principals if they control the crime individually, jointly with a co-perpetrator, indirectly via an organized apparatus of power, or as indirect co-perpetrators (via a combination of the previous doctrines). As the ICC adopted the control requirement, however, some of its decisions have allowed lower mental states such as recklessness or dolus eventualis to meet the standard for principal perpetration under the Control Theory. Other decisions have asserted that intent or knowledge is required though their definitions of knowledge include a risk of future events - a definition uncomfortably similar to recklessness. The following essay argues that the ICC should reverse its approach: instead of combining the essential contribution' element with a weak mental requirement (its current doctrine), the ICC should deemphasize control by lowering the essential contribution requirement and reinvigorating the required mental state. In short, the ICC should take a second look at subjective theories of perpetration that define principals as those with the intention to carry out the crime (or joint intention in the case of co-perpetrators) and who contribute to the effort. The ICC's Control Theory represents an over-correction to the perceived excesses of the subjective approach - excesses that could be fixed without resorting to the ICC's current ersatz-Control Theory.
\end{abstract}

\section{Introduction}

The following essay offers a brief history of theories of perpetration within international criminal law so as to situate the current debates over the ICC's Control Theory within the proper context. I then conclude that the ICC's Control Theory represents an overcorrection based on perceived, but ultimately

* Professor of Law, Cornell Law School; member, Editorial Committee of this Journal. The author acknowledges comments and suggestions from Boris Burghardt, Gerhard Werle, Kai Ambos, James Stewart, Luis Chiesa, Robert Cryer, Elies van Sliedregt, Thomas Weigend, Máximo Langer, Kevin Heller, and Carl-Friedrich Stuckenberg. [jdo43@cornell.edu] 
misplaced, anxieties (both theoretical and practical) about the alleged failure of subjective theories to convincingly ground imputation of criminal conduct. Consequently, Part 4 lays out an alternate and less-drastic solution than the ICC Control Theory: revising the subjective approach with minor adjustments to produce a 'functional-subjective' approach to imputation ideally suited to the collective context. Part 4 not only responds to specific objections about the subjective approach but also briefly outlines how subjective imputation might be applied by the International Criminal Court. This brief critique is not designed to respond directly to Roxin's original version of the Control Theory, but rather to concentrate on the Control Theory as applied by the ICC Pre-Trial and Trial Chambers.

\section{A Revised, but not Revisionary, History of Modes of Liability}

At Nuremberg, the major trials were famously structured around the doctrine of conspiracy, which included the notion of a common plan or agreement. Conspiracy was controversial because it was considered a common-law doctrine well known for its excesses. In the United States, for example, it is both a substantive offence and a mode of liability; furthermore, the substantive offence (in most jurisdictions) does not merge with the completed offence, so that defendants can be charged with both conspiracy and murder - a form of double counting that still annoys defence counsel. As for the mode of liability, co-conspirators are vicariously responsible for the actions of the other co-conspirators, even those actions that stray from the common plan as long as they are reasonably foreseeable. ${ }^{1}$ US military lawyers recognized the value of these doctrines for describing the sum-total of Nazi criminality. In essence, the Nuremberg prosecution described the entire Nazi era (1923-1945) as a single conspiracy - spanning decades, thousands of individuals, and several continents. ${ }^{2}$ Nothing like it was before or after prosecuted at a criminal tribunal. Nonetheless, because of discomfort from civil law jurists at Nuremberg, the conspiracy doctrine yielded substantial complaints and in a compromise was only retained for crimes against peace - a crime that was already collective and where conspiracy could do little damage, so to speak. ${ }^{3}$

During the era of the ad hoc tribunals, from 1995 onwards, the doctrine of Joint Criminal Enterprise reigned, providing for principal liability for all

1 See Pinkerton v. United States, 328 U.S. 640, 648 (1946).

2 See Indictment, United States v. Göring et al., Trial of the Major War Criminals Before the International Military Tribunal, Vol. 1 (1947), at 30-35 (noting founding of Nazi party in 1920 which became the instrument of cohesion among the defendants and their co-conspirators and an instrument for the carrying out of the aims and purposes of their conspiracy').

3 On this point, see G.P. Fletcher, Amicus Curiae Brief of Specialists in Conspiracy and International Law in Support of Petitioner', 2006 WL 53979, filed in Hamdan v. Rumsfeld, 548 U.S. 557 (2006). 
members of joint endeavours to commit international crimes. This is often described as a subjective theory of perpetration because it is based on the mens rea of agreeing to the common plan or enterprise. This can be contrasted with the so-called 'objective' theory of perpetration that reigned - and continues to reign - in common law jurisdictions. Under the objective theory, only those who perform the actus reus of the criminal offence are labeled as principals to the crime; all others are declared mere accessories even if they ordered the crime. ${ }^{4}$ This produces a counter-intuitive and normatively unsatisfying result, and it more than anything else is the reason why US criminal law insists that accessories are equally culpable as principals and can be punished as such. ${ }^{5}$ Since the substantive law does not make the right distinctions, the distinctions are afforded fewer consequences.

The Stakić case represented one of the first international cases to search for a new way forward. ${ }^{6}$ Citing Claus Roxin, the ICTY Trial Chamber concluded that the JCE theory was both controversial and unnecessary - other solutions for macro-criminality should be explored. The Trial Chamber argued that Stakić could be convicted as a co-perpetrator under Roxin's Control Theory. The doctrine held great influence in German academic circles, was applied in several foreign jurisdictions, but was not yet governing law before the international tribunals. ${ }^{7}$ The theory labels as an indirect perpetrator (Täter hinter dem Täter) any individual who exercises control over the crime by using another individual (or individuals) to carry out the crime; these perpetrators are the masterminds (Hintermann) of atrocity. ${ }^{8}$ In cases of co-perpetration, individuals are principals if they exercise joint control over the crime as a collective unit. Although George Fletcher had included an extensive discussion of Roxin's Control Theory - or hegemony over the act theory — in his original edition of Rethinking Criminal Law, no other American criminal law scholar cited or discussed Roxin for decades. ${ }^{9}$

4 W. Blackstone, Commentaries on the Laws of England, Book II, section 34 ('A principal in the first degree, is he that is the actor, or absolute perpetrator, of the crime; and, in the second degree, he who is present, aiding and abetting the fact to be done.'); T.W. Hughes, A Treatise on Criminal Law and Procedure (1919), at 122, § 167.

518 U.S.C. $\S 2$.

6 Judgment, Milomir Stakić (IT-97-24-T), Trial Chamber II, 31 July 2003, § 440.

7 For a description of the foreign jurisdictions applying the Control Theory or variations of it, see K. Ambos, Treatise on International Criminal Law, Vol. 1: Foundations and General Part (Oxford University Press, 2013), at 114-118.

8 See C. Roxin, Täterschaft und Tatherrschaft (8th edn., De Gruyter Recht, 2006); M. Bohlander, Principles of German Criminal Law (Hart Publishing, 2009), at 159; M. Bohlander, The German Criminal Code: A Modern English Translation (Hart Publishing, 2008), at 90; K. Ambos, Article 25 Individual Criminal Responsibility', in O. Triffterer (ed.), Commentary on the Rome Statute of the International Criminal Court (1st edn., C.H. Beck, 1999) 743, at 752 n. 68.

9 See G.P Fletcher, Rethinking Criminal Law (Reprint edn., Oxford University Press, 2010), at 655-659. Osiel performed an extensive discussion of the Control Theory but not until much later. See M. Osiel, 'The Banality of Good: Aligning Incentives Against Mass Atrocity', 105 Columbia Law Review (2005) 1751-1862; M. Osiel, Making Sense of Mass Atrocity (Cambridge University Press, 2009), at 85-114. 
Although the innovative Stakić judgment was summarily rejected by the ICTY Appeals Chamber, ${ }^{10}$ the Control Theory fared much better at the ICC, where the earliest Confirmation of Charges decisions from the Pre-Trial Chamber all applied Roxin's Control Theory of Perpetration. The first full judgment - Lubanga - followed this course of action and it now appears that the Control Theory is firmly entrenched in ICC doctrine and practice, despite no mention of it in the Rome Statute other than the phrase 'jointly with another or through another person' in Article 25(3)(a).

In the present essay, I offer a critical assessment of the ICC Control Theory and evaluate its merits against competing 'subjective' approaches of imputation based squarely on mens rea. Consequently, Part 3 will lay out the exact criteria for the Control Theory as applied by the relevant ICC chambers. Part 3 will then proceed to canvass the relevant objections to the ICC's Control Theory, including charges of vagueness and indeterminacy stemming from the inclusion of an 'essential contribution' prong within its standard. Although such objections are pressing, I will argue ultimately that the ICC's abandonment of a robust mens rea requirement is far more important.

Part 4 will then lay the groundwork for a competing theory of perpetration based on subjective imputation. This theory — labelled Joint Intentions substitutes the control criterion for a more robust mens rea requirement built on the particular mental states that emerge during collective action. In particular, I will provide a side-by-side comparison that demonstrates that the Joint Intentions theory provides equally plausible - and in some marginal cases more plausible - results than the ICC's Control Theory. Significantly, I will diagnose the shift away from subjective theories of imputation as an overcorrection. Instead of abandoning subjective theories in favour of the ICC Control Theory, international courts should refine subjective theories of imputation to take into account the particular function of mental states in collective action situations. That is precisely what the Joint Intentions theory does.

\section{The Control Theory of Perpetration as Over-Correction}

In Lubanga, the ICC Pre-Trial Chamber listed the formal requirements for co-perpetration as including: (1) a common plan or agreement between multiple individuals; ${ }^{11}$ (2) coordinated essential contribution by each co-perpetrator resulting in the realization of the objective elements of the crime, ${ }^{12}$ (3) satisfaction of subjective elements of the substantive crime; ${ }^{13}$ (4) mutual awareness and acceptance that implementation of the common plan may result in

10 Judgment, Milomir Stakić (IT-97-24-A), Appeals Chamber, 22 March 2006, § 62.

11 Decision on the Confirmation of Charges, Lubanga (ICC-01/01-01/06), Pre-Trial Chamber I, 29 January 2007, 343 (hereinafter 'Lubanga, Confirmation of Charges').

12 Lubanga, Confirmation of Charges, $\$ 346$.

13 Lubanga, Confirmation of Charges, $\S 349$. 
the realization of the objective elements of the crime; ${ }^{14}$ and (5) defendant's subjective awareness of the factual circumstances enabling him or her to jointly control the crime. ${ }^{15}$

In the final Lubanga judgment, the ICC Trial Chamber refined this analysis. It concluded that a combined reading of Articles 25(3)(a) and 30 lead to the conclusion that committing the crime in question does not need to be the over-arching goal of the co-perpetrators. ${ }^{16}$ It also clarified that control resided in the group itself, not each individual who co-perpetrates the crime. 'None of the participants exercises, individually, control over the crime as a whole but, instead, the control over the crime falls in the hands of the collective as such,' the Chamber declared. ${ }^{17}$ However, the majority still maintained that the contribution of each defendant must be essential. ${ }^{18}$ Furthermore, the court noted that in the view of the majority "what is decisive is whether the co-perpetrator performs an essential role in accordance with the common plan, and it is in this sense that his contribution, as it relates to the exercise of the role and functions assigned to him, must be essential. ${ }^{19}$

The first major criticism of the ICC's control theory is that it is both vague and indeterminate. ${ }^{20}$ The vagueness stems from the need to assess whether the defendant had control over the crime. Control is assessed on the basis of the existence of a common plan as well as an essential contribution; contributions are essential if the crime would not have occurred without the defendant's contributions. ${ }^{21}$ This definition of the essential contribution requirement requires counter-factual thinking. ${ }^{22}$ It requires asking a question about possible worlds: In a world where the defendant is absent from the scenario, would the crime still have occurred? If not, then the defendant's actions are essential to the outcome.

The most obvious objection is that such determinations are notoriously indeterminate. How does one know what would happen in such a world if such a world does not exist? Indeed, there is a rich debate in the formal logic literature on the truth-value of such counterfactual statements; at first glance it appears that they have no truth-value at all. ${ }^{23}$ Of course, this form of global scepticism

14 Lubanga, Confirmation of Charges, § 361.

15 Lubanga, Confirmation of Charges, $\$ 366$.

16 Judgment, Lubanga (ICC-01/04-01/06), Trial Chamber I, 14 March 2012, § 985 (hereinafter cited as 'Lubanga, Judgment').

17 Lubanga, Judgment, §994.

18 Lubanga, Judgment, §999.

19 Lubanga, Judgment, $\S 1000$.

20 For a discussion, see T. Weigend, 'Intent, Mistake of Law, and Co-Perpetration in the Lubanga Decision on Confirmation of Charges', 6 Journal of International Criminal Justice (JICJ) (2008) 471.

21 See e.g. Separate and Dissenting Opinion Judge Fulford, Judgment, Lubanga (ICC-01/04-01/06), Trial Chamber I, 14 March 2012, §17.

22 Ibid.

23 See N. Goodman, Fact, Fiction and Forecast (4th edn., Harvard University Press, 1983), at 36 ('Plainly, the truth-value of a counterfactual does not derive simply from the truth-value of its components; for since the antecedent and consequent of every counterfactual are both false, all counterfactuals will have the same truth-value by any truth-functional criterion. 
is unwarranted, especially since causal stories inevitably involve some counterfactual thinking and the law is replete with causal connections. ${ }^{24}$ It would be unfair to impose on the ICC's Control Theory a greater demand for empirical precision above and beyond what is required for any judicial application of basic principles of causation. In any case hinging on but-for causation (including cases dealing with omissions), counter-factual thinking is inescapable. So the objection is not the existence of counter-factual analysis per se, but rather whether and to what extent the existence of counter-factual analysis should be regarded as a cost or benefit of the doctrine when analyzing competing doctrines and evaluating both the ease with which fact-finders can apply them, and the degree to which these doctrinal requirements yield normatively plausible answers regarding relative-blameworthiness. It is one thing to employ counterfactual analysis to determine but-for causation, a relatively uncontroversial element of most cases that is usually easily satisfied (except in cases of over-determination), and quite another to use counterfactual analysis as the sine qua non of principal perpetratorship via the essential contribution requirement.

Nonetheless, it is the case that vagueness remains and the ICC has not provided sufficient direction about how to resolve this vagueness with regard to essentiality. In particular, if the defendant had not engaged in the conduct, it is possible that some crime would have occurred, but would this crime be the same crime as the crime that did in fact occur? Once one considers possible worlds, the variations are substantial. If the defendant had not participated, maybe the illegal attack on a civilian village would not have occurred, but if the same attack would simply have occurred on a different village, is this considered the same crime or a different crime? Or what if different military personnel were used in the assault but the victims were the same? Or what if both the attacking personnel and victims were the same, but the ordinances were slightly different? Or what if the defendant's absence would transform a case of genocide into a case of crimes against humanity, where all other facts are the same (same number of victims) with the only different being the absence of genocidal intent?

It is too simplistic to say simply that 'the crime' would not have occurred, unless one has a theory that explains the unity of the crime across modal universes. Without such a theory, the very concept of 'the crime' is vague and indeterminate. Of course, answers could be provided here. One might say, for example, that if the possible world is sufficiently close to the actual world in the relevant aspects, then the essentiality criterion is satisfied. One might then cash out 'relevant aspects' with regard to the elements of the offence, although leaving flexibility that not every element of the offence need be

Counterfactual connection must be defined in some quite different way.). Indeed, possibleworld semantics can be seen as a solution to his potential problem. See D. Lewis, Counterfactuals (2nd edn., Wiley-Blackwell, 2011), at 13.

24 But see M.S. Moore, Causation and Responsibility: An Essay in Law, Morals, and Metaphysics (Oxford University Press, 2009), at 425. 
satisfied. This does not constitute a complete answer, but it provides a pathway to the type of analysis that would need to be provided in order to render an essentiality criterion clear, determinate, and readily applicable by fact finders.

However, the leading proposed solution to the problem of the essential contribution requirement is far more radical. The ICC Office of the Prosecutor has now suggested in multiple filings before the Court that Article 25(3)(a) does not require an essential contribution at all, but rather only a substantial contribution. $^{25}$ The Lubanga Trial Chamber majority explicitly rejected this proposal and reiterated the centrality of the essential contribution requirement. Nonetheless, the OTP continues to press the point vigorously. As evidence for its position, the OTP has argued that Roxin was not wedded to the essential contribution requirement and favours a substantial contribution requirement in some cases. ${ }^{26}$

At this point it is necessary to distinguish between two levels of essentiality. First, there is the question of whether the group itself has control over the crime, and whether the crime could have occurred but for the group's control over it. After this is established, the analysis shifts to the individual defendant and whether he or she, as a co-perpetrator, individually provided an essential contribution. One could, coherently, require essentiality at the group level but drop it at the individual level; in its place one substitutes a substantial contribution at the individual level. This solves the counter-factual question at the individual level, but not at the collective level, where it must still be determined that the collective controlled the crime and had the ability to frustrate its execution or not. What does it mean for control to reside at the level of the collective? As Roxin notes, control means the hypothetical ability to frustrate the crime; that still applies even if the required level of individual contribution is reduced.

However, deeper problems with the ICC's Control Theory lurk in the background and often go unexamined. In particular, the Lubanga Pre-Trial Chamber and Trial Chamber defined the mental elements in a notoriously lax way. This is predictable because the Control Theory is designed as a functional objective approach, which inevitably means that it deemphasizes the mental elements and places far less emphasis on them compared to a subjective approach to imputation. ${ }^{27}$ Specifically, the ICC does not even require the existence a common plan designed with a criminal objective in mind. The requirement of a common plan or agreement is satisfied even if it has a non-criminal

25 See Prosecution's Submissions on the Law of Indirect Co-Perpetration under Article 25(3)(a) of the Statute and Application for Notice to be given under Regulation 55(2) with Respect to William Samoei Ruto's Individual Criminal Responsibility, Ruto and Sang (ICC-01/09-01/11), Trial Chamber V, 3 July 2012.

26 See ibid., §12, citing C. Roxin, Täterschaft und Tatherrschaft (7th edn., De Gruyter Recht, 2000), at 280-285. I do not assert an opinion here regarding the correctness of the OTP's reading of Roxin's theory.

27 The Control Theory of Perpetration was originally designed as a corrective to the perceived excesses of the subjective theories of perpetration applied by German courts. For a discussion, see Bohlander, Principles of German Criminal Law, supra note 8, at 162. 
goal, just as long as the defendants foresee the possibility that criminal conduct, and the objective elements of the crime in question, will be brought into existence by the plan. ${ }^{28}$ This forms an example of dolus eventualis.

Although the Trial Chamber claimed to abandon dolus eventualis in the Lubanga Judgment, in fact it did so in name only. ${ }^{29}$ In particular, the Trial Chamber stated that the drafting history of the Rome Statute clearly pointed to the exclusion of dolus eventualis from Article $30 .{ }^{30}$ However, the Trial Chamber then smuggled dolus eventualis through the back door, by strangely concluding that elements of risk, danger, probability, and possibility were all inherent in the phrase 'in the ordinary course of events' from Article 30. This is a very strange reading indeed, since the Rome Statute drafters were clearly establishing acting with purpose or knowledge as default mental states. Many jurisdictions understand knowledge, and 'in the ordinary course of events' as pertaining to events that will occur with virtual certainty. ${ }^{32}$ The risk that events might occur — falling below virtual certainty — then accords with recklessness and dolus eventualis. To suggest that liability for risk-taking behaviour is consistent with 'in the ordinary course of events' is to read dolus eventualis into Article 30 in every way except changing the label. ${ }^{33}$

I will not repeat my substantive concerns about dolus eventualis here; I have done this elsewhere. ${ }^{34}$ But suffice it to say that if dolus eventualis is understood to be liability for the risk of future events that might occur, then it is inconsistent with both the language and drafting history of Article 30 of the Rome

28 Critical, see Ambos, Treatise on International Criminal Law, supra note 7, at 152 ('I am not convinced that a mere "critical element of criminality" suffices for a plan of co-perpetrators. After all, we are not dealing here with any plan (e.g. to pay a visit to Paris next weekend) but with a plan which forms the basis of a joint commission of a crime and, as a consequence, of the mutual attribution of the respective contributions of the co-perpetrators. Such a plan cannot be predominantly non-criminal but must at least — that would be my "minimum" — contain a more or less concrete crime to be committed, otherwise there is nothing (agreed) which could be mutually attributed.').

29 For a different interpretation of the Lubanga Judgment, see K. Ambos, 'The First Judgment of the International Criminal Court (Prosecutor v. Lubanga): A Comprehensive Analysis of the Legal Issues', 12 International Criminal Law Review (2012) 115, at 149-150.

30 See Lubanga, Judgment, §1011.

31 Ibid., § 1012 ("This prognosis involves consideration of the concepts of "possibility" and "probability", which are inherent to the notions of "risk" and "danger". Risk is defined as "danger, (exposure to) the possibility of loss, injury or other adverse circumstance"'). Consequently, under the Trial Chamber's reasoning, liability for future possible events meets the 'knowledge' standard just as long as the risk is not 'low'. This completely contradicts a typical definition of knowledge as virtual certainty that a future event will occur, and accords much more readily with recklessness.

32 See e.g. U.S. Model Penal Code $§ 2.02(2)(b)$.

33 The other avenue for bringing dolus eventualis into the Rome Statute is by utilizing the "unless otherwise provided' clause in Art. 30. For a strong defense of this solution, see G. Werle and F. Jessberger, "Unless Otherwise Provided": Article 30 of the Rome Statute and the Mental Element of Crimes under International Criminal Law', 3 JICJ (2005) 35-55. See also S. Wirth, 'Co-Perpetration in the Lubanga Trial Judgment', 10 JICJ (2012) 971, at 995.

34 See e.g. J.D. Ohlin, 'Targeting and the Concept of Intent', 35 Michigan Journal of International Law (2013) 79-130. 
Statute. ${ }^{35}$ And the frequent - and interesting — debate over whether dolus eventualis is the same as common law recklessness or a higher mental state is largely a distraction here. The key element is that liability for risk-taking behaviour is not consistent with Article 30 and is only appropriate if 'otherwise provided' by the elements of a particular offence. The Control Theory does not meet this standard for 'unless otherwise provided'. Suggesting that it does would gut the Article 30 default mens rea standard of all rigor and meaning as a guardian of robust mental states in the practice of the ICC.

My point here is not to rehash the debates about mental states. Rather, my point is simply to acknowledge that the ICC's particular version of the Control Theory, when combined with a liberal reading of article 30, and dolus eventualis, has produced a particular version of the Control Theory that is widely expansive. In the end, it makes a bargain that I feel is unwarranted and counterproductive: it tightens up the objective elements by focusing on control, but then loosens or deemphasizes the subjective elements. As a strategic matter, this constitutes a mistake. ${ }^{36}$ The following section provides a side-by-side comparison to make this point.

\section{A Subjective-Functional Theory of Imputation as an Alternative}

As indicated in the previous section, the current doctrine's de-emphasis on subjective elements is a strategic mistake, an overcorrection in response to historical problems with subjective approaches. In Germany, the apex of the subjective approach is widely considered to be Stashynskij, involving a KGB agent

35 The drafters of the Rome Statute specifically excluded a draft provision in Art. 30 that would have covered dolus eventualis and recklessness. See Chairman's Text, UN Doc. A/AC.249/1997/ WG.2/CRP.4. See also UN Doc. A/CONF.183/DC/R.76. For a discussion, see W.A. Schabas, The International Criminal Court: A Commentary on the Rome Statute (Oxford University Press, 2010), at 473; R.S. Clark, 'Drafting a General Part to a Penal Code: Some Thoughts Inspired by the Negotiations of the Rome Statute of the International Criminal Court and by the Court's First Substantive Law Discussion in the Lubanga Dyilo Confirmation Proceedings', 19 Criminal Law Forum (2008) 619. Other ICC decisions have recognized this argument and excluded dolus eventualis from Art. 30. See Confirmation of Charges, Bemba (ICC-01/05-01/08), Pre-Trial Chamber II, 15 June, 2009, § 366 \& n. 461, citing Report of the Working Group on General Principles of Criminal Law, UN Doc. A/CONF.183/C.1/WGGP/L.4, at 255. See also K. Ambos, 'General Principles of Criminal law in the Rome Statute', 10 Criminal Law Forum (1999) 1, at 21-22 (arguing that dolus eventualis is inconsistent with Art. 30 ICCSt.).

36 In this vein, consider C. Kutz, Complicity: Ethics and Law for a Collective Age (Cambridge University Press, 2000), at 74, who concentrates on 'participatory intentions' to ground liability and likewise deemphasizes contribution requirements since individuals frequently make little difference to large projects. Kutz also concludes that different intentions might yield different levels of responsibility. See ibid at 160. (However, one crucial difference should be noted: I suggest lowering the contribution requirement, not eliminating it.) Victor Tadros has also recently suggested that intentions are relevant in cases where causal contributions are uncertain or over-determined. See V. Tadros, The Ends of Harm: The Moral Foundations of Criminal Law (Oxford University Press, 2011), at 159. 
who fled to West Berlin and was subsequently prosecuted for murdering dissidents under orders from the KGB ${ }^{37}$ An earlier case in 1940 involved an aunt's killing of her newborn niece in a bathtub, reportedly performed for the sake of the aunt's sister (the baby's mother). ${ }^{38}$ In both cases, the German courts concluded that the physical perpetrators were mere accomplices and could not be convicted as principal perpetrators because they did not share the animus auctoris and did not make the crime their own. ${ }^{39}$ Stashynskij performed the killing for the KGB, while the aunt drowned the baby for her sister. These results were controversial and academic dissatisfaction with them and similar cases helped pave the way for the Control Theory. ${ }^{40}$

However, the normatively implausible results in Stashynskij and Bathtub have less to do with a subjective approach simpliciter but are more likely the product of the particularly extreme subjective theory applied by the German courts in these cases. ${ }^{41}$ This extreme theory is problematic, not because it is subjective, but because it conflates motive with intention. Neither Stashynskij nor the aunt have particularly strong personal motives for performing the killing, though both performed their respective killings purposely, and their lack of a strong personal motive should not disqualify them from being principals even under a subjective theory. Indeed, as the following section will demonstrate, even a Joint Intentions Theory would probably label each defendant as co-perpetrators (depending on the specific facts), since Stashynskij arguably shared a joint intention with the KGB to carry out the killings, while the aunt presumably shared a joint intention with her sister that they should kill the baby. The fact that the physical perpetrator performed the act primarily for the benefit of a third-party beneficiary should not be relevant to their status as co-perpetrators. This has nothing to do with the subjective approach per se.

This suggests that while past applications of the extreme subjective theory have been problematic, it is unwise to give up on the subjective approach to perpetration simply because its extreme version was extreme. The current section will now briefly address two potential problems, including the vagueness of mental states and problems regarding their attribution, as well as academic controversy regarding Joint Criminal Enterprise. As should be clear from our discussion of Stashynskij and Bathtub, it is best not to impugn an entire approach simply because one application of it, namely JCE III, was discredited. This section will then conclude with some additional reasons in favour of subjective imputation.

37 See 18 BGHSt 87 (1962). The Stashynskij case gets sustained treatment in Fletcher's Rethinking, supra note 9 , at $657-659$.

38 The Bathtub Case, 74 RGSt 84 (1940).

39 See Bohlander, Principles of German Criminal Law, supra note 8, at 162-163.

40 Indeed, the results in the Stashynskij and Bathtub cases are problematic because they descend into solipsism - the defendants could not be principals because they did not view themselves as primary actors and they thought of themselves as supporting others.

41 Bohlander, Principles of German Criminal Law, supra note 8, at 162 n. 14. 


\section{A. Two Objections Reconsidered}

First, some scholars have disfavoured subjective approaches because mental states are themselves subject to criticism for being vague and indeterminate. ${ }^{42}$ Basing a criminal conviction on a mental state requires assessing the mental attributes of a defendant - a difficult task to be sure. However, opponents often deploy their scepticism about mental states in an inconsistent and strategic manner. Opponents claim that mental states are impossible or difficult to verify in criminal cases but then they attribute them - without difficulty - in their daily lives. Indeed, having a simple conversation with an interlocutor is impossible without attributing mental states to one's conversant. ${ }^{43}$ Indeed, attribution of mental states is part and parcel with behaviour interpretation. Let me explain. Since direct epistemic access to a defendant's mental states is impossible, then on the basis of behaviour one attributes mental states in order to make sense of an agent's behaviour, to figure out what they are doing and why they are doing it. In fact, everyone does this all the time, and although insincerity is always a risk, we are also capable of ferreting out people who report fallacious mental states when these reports fail to make the best sense of their behaviour. ${ }^{44}$ The only situation where behaviour attribution is unnecessary is in cases of self-knowledge, where we each have direct access to our own mental states without needing to resort to behaviour interpretation to posit mental states. In a criminal case, this takes the form of attributing the mental state that is one part of developing the best explanation of the defendant's behaviour.

One might also object that subjective theories of imputation collapse into object theories if mental states can only be attributed on the basis of outward behaviour. Consequently, it would appear that subject mental states are just proxies for the objective behaviour which is then used as the relevant evidence for attributing mental states. Under this argument, there is no true subjective imputation; there is either a direct objective theory or an indirect objective theory mediated through mental states. But this objection is misplaced because it confuses the two levels of the analysis. At the level of criminal law theory, the subjective theory of imputation uses mental requirements, as a normative matter, as the chief hallmarks for determining liability and distinguishing principals from accessories. At a deeper level, however, mental states are known epistemically by virtue of our ability to attribute mental states through the process of behaviour interpretation. We assume that someone who takes a drink of water was thirsty and bore a mental desire to quench his thirst. However, this is quite different from using the objective elements of the offence, as a normative matter, as the hallmarks for liability and differentiating between principals and accessories. These are simply two different levels of analysis.

42 See e.g. K. Shapira-Ettinger, 'The Conundrum of Mental States: Substantive Rules and Evidence Combined', 28 Cardozo Law Review (2007) 2577.

43 See P. Pettit, The Common Mind (Oxford University Press, 1993).

44 See D. Davidson, 'Belief and the Basis of Meaning', in idem, Inquiries into Truth and Interpretation (2nd edn., Oxford University Press, 2001), at 141. 
Second, in more recent history, modes of liability based on subjective imputation have received a poor reputation because Joint Criminal Enterprise was beset with problems that generated enormous scholarly criticism. ${ }^{45}$ But the problems with JCE had nothing to do with the subjective nature of its imputation. Rather, the difficulty stemmed from the lack of differentiation among participants in the criminal plan, such that defendants who intended the crime (JCE I) and those who merely foresee the possibility of the crime (JCE III) were considered equally guilty. ${ }^{46}$ Furthermore, there were substantial concerns about the level of contribution required, and the appropriate link between the defendants and the physical perpetrators of the crimes. ${ }^{47}$ But none of these problems are direct criticisms of subjective forms of imputation. To suggest otherwise is to engage in guilt by doctrinal association.

As a normative matter, why should mens rea be the centre of analysis for a theory of perpetration? Why are mental elements more important than objective elements? Although the literature on this question is vast and deep, ${ }^{48}$ and cannot be repeated here, there are nonetheless key points that deserve mention. Mental elements - especially volitional ones - represent the defendant's desire to bring about a state of affairs in the world. As such, these volitional elements represent a moral choice, a decision for which agents will be called to account by their social communities and the criminal law. Volitional elements are the hallmarks of our rational agency and, by extension, responsibility and desert. As human agents in the world, there is much beyond our control, but our decisions are one unassailable exemplar of moral responsibility. Although developments in genetics and brain science allegedly chip away at our free agency, it is nonetheless undeniable that human beings assume their own free agency (and the agency of others) in deciding which course of action to take in the world. ${ }^{49}$

45 The examples are too numerous to mention in detail. For a short list, consider A.M. Danner and J.S. Martinez, 'Guilty Associations: Joint Criminal Enterprise, Command Responsibility, and the Development of International Criminal Law', 93 California Law Review (2005) 75, at 164; J.D. Ohlin, 'Three Conceptual Problems with the Doctrine of Joint Criminal Enterprise', 5 JICJ (2007) 69, at 78; K. Ambos, 'Joint Criminal Enterprise and Command Responsibility', 5 JICJ (2007) 159; Joint Criminal Enterprise Brief of Amicus Curaie Kai Ambos, Kaing Guek Eav (Duch Case) (001/18-07-2007/ECCC/OCIJ), Pre-Trial Chamber II, 27 October, 2008, at 15.

46 See J.D. Ohlin, 'Joint Intentions to Commit International Crimes', 11 Chicago Journal of International Law (2011) 693, at 713 (arguing in favour of differentiation).

47 This issue came to the forefront after the ICTY held that defendants need not be members of the same JCE as the physical perpetrators. See Judgment, Brđanin (IT-99-36-A), Appeals Chamber, 3 April 2007, § 410.

48 See e.g. Fletcher, Rethinking Criminal Law, supra note 9, at 118 (famously distinguishing the pattern of subjective criminality from the pattern of manifest criminality).

49 See P.F. Strawson, 'Freedom and Resentment', in G. Watson (ed.), Free Will (Oxford University Press, 1982) 59, at 67. Sceptics criticize the criminal law's reliance on mental states for determining blameworthiness, but these critics deploy their scepticism strategically and hypocritically. They assume their own free agency when they engage in their own behaviour, but deny free agency in other contexts. See S.J. Morse, 'Criminal Responsibility and the Disappearing Person', 28 Cardozo Law Review (2007) 2545, at 2569-2575 ('The new neuroscience does not pose, and is unlikely ever to pose, a real threat to our fundamental conception of personhood 


\section{B. Joint or Shared Intentions in Collective Contexts}

So theories of subjective imputation have received a bad reputation for little reason. In what follows, I outline the basics of a subjective theory of imputation and explain why it gives more intuitive results than the ICC's version of the Control Theory.

The requirements of the new theory are that the defendant shared a joint intention with others that the group commits the crime in question. In order for a bona fide joint intention to exist, the individuals must have engaged in a collective consideration of the crime in question, how it will be achieved, and the division of labour required to produce the result. As Michael Bratman puts the point, a joint intention also requires that the individuals 'mesh subplans, i.e. coordinate not just the ultimate outcome of the plan but also how each component of the crime will interact with each other element of the joint endeavour. ${ }^{50}$ If two individuals pursue similar conduct with a mere glimmer of reaching similar outcomes, but without any consideration for how this will be achieved, this is mere parallelism, not coordinated activity based on a joint intention. Although coordinated activity usually stems from overt deliberation, the deliberation is a contingent fact of most cases and not an essential element; a joint intention might happen virtually spontaneously, as is the case with a lynching that includes a deadly and coordinated division of labour. ${ }^{51}$

An essential aspect of the joint intention theory is that the individuals in question share the same intention. In other words, the cognitive content of the intention is identical for the two individuals. Each person $a$ intends that the group $b$ commit the crime $y$ and each individual with the joint intention by definition has a mental state that shares the same cognitive structure as the mental state exhibited by the other co-perpetrators. The only difference is that the intentions are exhibited by different agents.

I call the Joint Intentions Theory an example of a subjective-functional approach to perpetration. In describing Roxin's particular contribution to theories of perpetration, one can distinguish between the objective approach that reigned in common law jurisdictions, the rival subjective approach focused on mens rea, and then Roxin's approach which insofar as it focuses on objective elements of control, was best described as a 'functional' variant of an objective theory with a mixture of subjective and objective elements. ${ }^{52}$ In a similar respect, the Joint Intentions Theory represents a functional variant of a subjective theory because it focuses on how subjective mens rea has a distinctive

and all that follows from it, including the concept of responsibility and related concepts, such as mens rea.').

50 M.E. Bratman, Faces of Intention: Selected Essays on Intention and Agency (Cambridge University Press, 1999), at 93-129.

51 See Trial of Erich Heyer and Six Others [Essen Lynching Case], British Military Court for the Trial of War Criminals, Essen, 18-19 and 21-22 December 1945. For an extensive discussion, see Ohlin, Joint Intentions to Commit International Crimes, supra note 45, at 726-727.

52 See Treatise on International Criminal Law, supra note 7, at 150; Fletcher, Rethinking Criminal Law, supra note 9, at 655 (describing the control theory as an 'intermediate' position). 
structure in cases of group action, with a mixture of subjective and objective elements.

What is the basis for favouring the Joint Intentions Theory over the ICC's Control Theory? Consider the following hypothetical scenarios. The ICC's Control Theory labels as a co-perpetrator a member of the group who is aware of the possibility of the criminal outcome and provides an essential or substantial contribution to the effort (depending on the version of the theory). The problem with this approach is that it encompasses individuals who should be regarded as mere accomplices. It should be remembered, for example, that accomplices share a unity of purpose with principal perpetrators and that therefore the existence of a common plan or agreement as the Control Theory describes it is perfectly consistent with the type of agreement that one often finds between principals and accomplices in many jurisdictions. ${ }^{53}$ In such cases, the accomplice who agrees to provide assistance in the form of a substantial contribution might be far removed from the central decision-making of the crime - they might, for instance, be a lower-level participant of the criminal endeavour who shares the common plan in order to provide midlevel assistance to the project which is directed at a non-criminal goal. Such individuals are part of a collective that controls the crime but their individual contribution to the crime is modest and the joint project is not criminal. Should they be a principal or a mere accomplice? Under the Lubanga Pre-Trial Chamber test, such individuals only need to be aware of the existence of the common plan, in the sense that the defendant "was aware that the consequence would occur in the ordinary course of events .... ${ }^{54}$ This is the main problem with the ICC's Control Theory, and even jettisoning or revising the essential contribution requirement is insufficient to guard against this excess. The excess resides not at the level of the contribution but rather at the level of the required mental element.

Compare this with the Joint Intentions Theory. Under the Joint Intentions theory, such individuals would most likely be labelled as mere accessories or accomplices. To be labelled a co-perpetrator, the defendant must share a bona fide joint intention with the other co-perpetrators. Mere awareness of the possibility of the crime occurring in the course of a non-criminal plan is insufficient, because awareness cannot yield a joint intention. A joint intention only arises when individuals each have an intention that the group as a whole commits the crime. Even awareness of the group's intent to commit the crime would be insufficient because such awareness would not constitute a joint intention. And this is precisely as it should be, since such individuals can and should be captured by Article 25(3)(d) of the Rome Statute, which provides for residual complicity liability for individuals who contribute to group endeavours. In the final analysis, what the Joint Intentions theory does is impose a

53 See Nye \& Nissen v. United States, 336 U.S. 613, 619 (1949); United States v. Peoni, 100 F.2d 401, 402 (2d Cir 1938).

54 See Lubanga, Confirmation of Charges, $\$ \S 360-361$ (defendants must be 'mutually aware and mutually accept ...'). 
heightened mental element in exchange for a weaker contribution requirement. I submit that this yields more intuitive answers to problem cases about perpetration.

Would this impermissibly capture mere accomplices? Is the Joint Intentions Theory too broad? In fact not; the doctrine would capture leadership individuals who engage in the planning of international crimes. This is more than just a contingent result; it is hardwired into the very requirements of the doctrine. By requiring a shared intention producing coordination and the meshing of sub-plans as the sine qua non of the Joint Intentions Theory, the doctrine ensures that leadership-level defendants are adequately punished for perpetrating international crimes by formulating the joint plans that brings them about. Such a leader is the true Hinterman - the mastermind who deserves the highest conviction as a principals or co-perpetrator. ${ }^{55}$

This is the real benefit of the Joint Intentions Theory. It provides a subjective theory of attribution, but not your Grandfather's subjective theory of perpetration. One might object that the Joint Intentions Theory represents a covert return to Joint Criminal Enterprise - a subjective approach to international crimes that dominated at the ad hoc tribunals. But one should remember that the real problem with JCE was not its subjective nature. Rather, the problems with JCE stemmed from two other aspects of the doctrine: its insistence on a de facto unitary approach to perpetration (whereby all members of the JCE were equally culpable) ${ }^{56}$ and its weakened mental state requirements in the form of JCE III, which allowed convictions as principals under a theory of dolus eventualis or recklessness. ${ }^{57}$ The Joint Intentions theory avoids both of these mistakes. ${ }^{58}$ Furthermore, the new approach is built with collective action in mind; indeed, it is based on the model of collective intentionality that underlies coordinated group activity. In this sense, it really is a

55 In Anglicizing the German phrase Hintermann into 'Hinterman', I follow Bohlander and others who have suggested that the English transliteration might be better suited to this unique context than the more general phrase 'mastermind'. See Bohlander, The German Criminal Code, supra note 8 , at 159 . The word 'Hinterman' captures the behindness of the perpetrator in a way that mastermind does not.

56 Although in theory aiding and abetting still applies as a separate mode of liability at the ICTY, its importance was greatly reduced because of the relative expansiveness of JCE. In this sense, Krstić functions as the exception that proves the rule.

57 See Judgment, Tadić (IT-94-1-A), Appeals Chamber, 15 July 1999, §§ 205-206. For an interesting analysis of recklessness, see M. Shahabuddeen, 'Judicial Creativity and Joint Criminal Enterprise', in S. Darcy and J. Powderly (eds), Judicial Creativity at the International Criminal Tribunals (Oxford University Press, 2010) 184, at 195-196 (restricting recklessness to cases where the defendant foresees that a crime might be necessary to achieve the common purpose and therefore conditionally intends it), though it is unclear if this restrictive reading of recklessness is consistent either with Tadić or with the actual practice of the ICTY in JCE III cases.

58 One might argue that the differences are purely cosmetic. Under the Joint Intentions theory, those who do not share the intent cannot be convicted as principals, though they might be convicted as accessories. Under JCE, those who do not share the intent are convicted under a distinct category, namely JCE III. Are these results essentially the same? In one sense yes, although there is a substantial difference in the JCE doctrine's insistence that JCE I and JCE III represent equivalent convictions rather than representative of a differentiated models. 
functional-subjective approach. It provides a sui generis theory of subjective imputation for macro-criminality.

To show how the theory would work in the international context, consider the following example: a group of governmental ministers are working with their prime minister to design a 'solution' posed by a minority ethnic group that they wish to expel from their territory. Although the levels of their contributions vary, they all share the same mental state: they each desire that the group collectively commit the crime of persecution as a crime against humanity. Implicit in that joint intention is that each individual participated in the formation of the coordinated distribution of labor and also the meshing of subplans.

One might object that in most criminal cases the Joint Intentions Theory will not yield differences answers on liability than the Control Theory. Perhaps Thomas Weigend was right when he noted that more ink has been spilt, both in German criminal law and international criminal law, on carving out very small distinctions. ${ }^{59}$ And so it might seem with the Control Theory and the Joint Intentions Theory. In both, government ministers could be charged and convicted as principals, either because they control the crime or because they share a joint intention that the collective commit the crime. Both are theoretical pathways to the same conviction. Should we care which theory is adopted by international courts?

Yes, we should care. In the main, different theories of perpetration will yield the same answers. Most situations are over-determined in the sense that the perpetrators will fulfill the criteria for multiple theories of perpetration. ${ }^{60}$ Indeed this is the same in domestic jurisdictions, where many defendants will fulfill the criteria for both accomplice liability and conspiracy liability, making the choice between the doctrines a question of prosecutorial strategy. But at the margins different modes of liability will yield different answers. They will give different answers in crucial cases, and in many respects the criminal law is built to deal coherently and convincingly with difficult cases at the margins, even if they appear far less frequently than the standard cases. The Joint Intentions Theory will convict as principals only those individuals who desire that the group commit the crime and who participate in the group-level deliberation that resulted in that joint intention and coordinated elements of the plan by meshing sub-plans. In contrast, the ICC's Control Theory will convict as principals individuals who belong to a collective project dedicated to noncriminal goals but are aware of the risk of an international crime being

59 See T. Weigend, 'Thomas Weigend comments on James Stewart's The End of 'Modes of Liability' for International Crimes', Opinio Juris, 22 March 2012, available online at http://opiniojuris.org/ 2012/03/22/ljil-weigend-comments/ (visited 14 February 2014).

60 That being said, the differences will show up even for core cases where the objective theory of perpetration is concerned. In that case, the objective theory defines perpetrators as those who perform the actus reus of the crime, and in both the Control Theory and the Joint Intentions theory, the defendant will likely have not physically perpetrated the crime. 
committed. Such individuals are reckless as to the final result and should not be equated with individuals who genuinely share a joint intention that the group commits the crime.

At this point, an objection could be raised. Does the Joint Intentions Theory need to be a stand-alone theory, a full replacement for the ICC's Control Theory? Or could it be imported into the ICC's Control Theory and act as a gloss on the required mental element for Control Theory cases of co-perpetration? This is certainly possible and it gives us A and B options for the theory. Under the A option, the Joint Intentions theory is a full replacement for the ICC's Control Theory, and it swaps the ICC Control Theory's weak mental element and heightened contribution requirement for a much stronger mental element but a weaker contribution requirement. On the other hand, under the B option, the Joint Intentions theory would simply provide an amendment to the ICC's Control Theory in the form of a heightened mental element specifically attuned to the cognitive structure of group intentions in cases of collective crimes. Indeed there might be substantial reasons to support the B option. For some, the real weakness of the control theory is its insufficient attention to the required mental element — a situation that could be resolved by reference to an embedded Joint Intentions Theory. This would yield a theory of attribution with both a robust mental element and a robust contribution requirement.

Option B - revising the ICC's Control Theory - would require moving the common plan or agreement requirement from the objective elements to the subjective elements, or at the very least adding a parallel requirement on the subjective side. And it would require abandoning the notion of dolus eventualis and non-criminal agreements within the scope of the Control Theory. But it would retain the other laudable aspects of the Control Theory, in particular its attempt to find an intermediate position between objective and subjective theories of imputation. In the end, it would simply tip the Control Theory's balance back to the subjective side by one degree, whereas in its current manifestation the ICC's Control Theory is tipped toward the objective side.

\section{Conclusion}

Tightening up the mental elements for principal perpetration would have additional benefits. For example, the application of indirect co-perpetration has produced substantial anxiety among both scholars and jurists who worry about the attribution of liability between defendants who are removed from the physical perpetrators along two axes - a vertical axis and a horizontal axis. $^{61}$ Indirect co-perpetrators collaborate with co-perpetrations who then

61 See J.D. Ohlin, 'Second-Order Linking Principles: Combining Vertical and Horizontal Modes of Liability', 25 Leiden Journal of International Law (2012) 771. For an excellent discussion, see also Ambos, Treatise on International Criminal Law, supra note 7, at 158; E. van Sliedregt, Individual Criminal Responsibility in International Law (Oxford University Press, 2012), at 170. 
delegate their contribution to subordinates along a vertical axis. Such defendants are thereby twice removed from the scene of the crime. Is this attribution of liability warranted? The Joint Intentions Theory provides an answer in the affirmative, if and only if the stringent conditions for the theory are met. If the co-perpetrators along the horizontal axis are unified in intention and purpose, they form an integrated collective whose actions are properly attributable to its members. Only a collective defined with a robust mental element will be sufficiently integrated to satisfy these anxieties.

This raises a final question. If we abandoned or revised the Control Theory, how should recklessness be handled in international criminal law? Part of the problem diagnosed in this Essay stems from the lack of distinct criminal offences in international law for crimes of recklessness. In a domestic system, if a defendant engages in risky behavior resulting in the death of an innocent victim, the defendant can be convicted of manslaughter or some other homicidal offence that covers the same conceptual ground. Unfortunately, no similar conceptual space exists in international criminal law-at least not at the level of the chapeau offences. You are either guilty of crimes against humanity or you are not; there is no separate offence for recklessness. One possibility would be to create one, although creating distinct offences outside of the statutory scheme of the Rome Statute is problematic from the perspective of the principle of legality. $^{62}$

The second-best solution is to deny reckless perpetrators the status of principals, i.e. to deny them their status as full-blown principals. By downgrading their status to mere accomplices or accessories, you express the distinction between them and those who act with full-blown intent, a distinction that might normally be expressed in the form of a different offence for recklessness. I count this as a normatively desirable result because those who desire the crime should be differentiated from those who merely foresee and accept their possibility. ${ }^{63}$ The category of accomplices might also capture those individuals who act with some degree of intent but do not fulfil the robust mens rea

62 In this sense, the recent history of command responsibility represents a cautionary tale. Scholars and some courts have argued that command responsibility represents liability for a distinct offence of omission. Although this solution solves many problems, it causes many more since the offence is not listed in the special part of the Rome Statute or any of the other ad hoc tribunal statutes. For a discussion, see D. Robinson, 'How Command Responsibility Got So Complicated: A Culpability Contradiction, Its Obfuscation, and an Elegant Solution', 13 Melbourne Journal of International Law (2012) 1.

63 It should be noted that although I support a differentiated model of perpetration, I do not conclude that all cases of accomplice liability demand automatic mitigation in the form of a sentence reduction. It may be the case that a crime is so significant that even aiding and abetting its commission deserves a life sentence. This may produce the curious result that the accomplice and the principal perpetrator receive the same sentence, but the opposite result is even more dissatisfying. The extrinsic fact that others are more culpable should not serve as a reason to downgrade the punishment of the other participants, whose blameworthiness and punishment ought to be based on purely intrinsic factors related to the blameworthiness of their conduct. 
standards for a joint intention. Consider individuals who desire that the crime occurs but play no role in the deliberations or coordinated division of labour, or the meshing of sub-plans. Such individuals have an intention but not a joint intention in the special meaning that the phrase occupies in this theory. They too would be classified as accomplices to the group crime, since the subjective criteria for full group vicarious liability would not be satisfied in this instance. 